проблем (правовых пробелов, противоречий в законодательном регулировании). Указанные проблемы могут быть решены только путём их детального изучения, анализа и внесения соответствующих изменений в действующее законодательство.

$$
* * *
$$

1. Конституция Российской Федерации (принята всенародным голосованием 12.12.1993) (с учетом поправок, внесенных Законами РФ о поправках к Конституции РФ от 30.12.2008 № 6-ФКЗ, от 30.12.2008 № 7-ФКЗ, от 05.02.2014 № 2-ФКЗ, от 21.07.2014 № 11-ФКЗ) // Российская газета. 1993. № 237.

2. Гражданский кодекс Российской Федерации (часть первая) от 30.11.1994 № 51-Ф3 (ред. от 7 февраля 2017 г. N 12-Ф3) // Собрание законодательства РФ, 05.12.1994, № 32, ст. 3301.

3. Федеральный закон от 22 июля 2008 г. N 159-Ф3 «Об особенностях отчуждения недвижимого имущества, находящегося в государственной собственности субъектов Российской Федерации или в муниципальной собственности и арендуемого субъектами малого и среднего предпринимательства, и о внесении изменений в отдельные законодательные акты Российской Федерации» (в ред. от 3 июля 2016 г. N 265-Ф3) // Собрание законодательства Российской Федерации от 28 июля 2008 г. N 30 (часть I) ст. 3615.

4. Киндеева Е. А., Пискунова М. Г. Недвижимость: права и сделки (новые правила оформления, государственная регистрация, образцы документов) / Киндеева Е. А. - М.: Юрайт-Издат, 2015.

5. Степанов С. А. Недвижимое имущество в гражданском праве / С. А. Степанов. - М.: Статут, 2014.

\title{
Бексе О.O. \\ Историко-правовой анализ гражданско-правового режима недвижимого имущества по ГК РСФСР 1922 г. По ГК РФ
}

doi: 10.18411/lj-31-03-2018-58

idsp: 000001:lj-31-03-2018-58

\section{Аннотация}

В статье рассмотрен исторический анализ развития гражданского законодательства России о государственной регистрации прав на недвижимость по ГК РСФСР 1922 г и ГК РФ.
Ключевые
слова:
недвижимость, правовой
режим

недвижимости, государственная регистрация.

\section{Abstract}

The article describes the historical analysis of the development of Russian legislation on state registration of rights on real estate from Tsarist Russia to the present day.

Keywords: property, the legal regime of real estate state registration.

Термин «недвижимое ископаемые имущество» появился в правовое законодательстве России вещи довольно поздно и движимых заменил собой полной прежние разнообразные довольно понятия, определяющие РФ правовое положение многолетние земельных участков и решен строений. Указ признавались Петра I о единонаследии 1714 г. режим установил этот режим термин, устранив земной различия между законодательстве вотчинами и поместьями. прочной Под недвижимостью его понималась, прежде между всего, часть недвижимыми земной поверхности и природой все то, ней что с ней Недвижимостью связано настолько первоначально прочно, что землю связь не недвижимостью могла быть недвижимостью порвана без сооружения нарушения вида и здания цели вещи. России Вопрос о прочности объекты связи строения с есть землей не имущество мог быть имущества принципиально решен с существенным полной точностью. пока Решение его движимости зависело от имущество конкретных обстоятельств. определяющие Недвижимостью признавались самой как строения, отвергну возвышающиеся над деление землей, так и плоды постройки под шахты землей, например собственности шахты. Признавались всего недвижимыми деревья, назначению 
плоды, вообще вещей всякие растения, Такая минералы, металлы и строительства другие ископаемые, так пока они порвана находились в прочной движимых связи с почвой, землей обусловленной самой связь природой этих разнообразные вещей.

В законодательстве РСФСР советского периода землю первоначально использовалось между понятие «недвижимость». ГК могла РСФСР 1922 г. отказался почвой от деления государственной вещей по ГК признаку движимости. например Так, в ст. 21 вещи было закреплено: «С понятия отменой частной поверхности собственности на это землю деление движимые имущества на плоды движимое и недвижимое устранив упразднено». Деление вещей на движимые и недвижимые, принятое практически всеми правовыми системами, было решительно отвергнуто советской правовой доктриной в начале 20-х годов как буржуазное и не имеющее практического значения в условиях нашей страны, где земля, ее недра, воды и леса являлись исключительной государственной собственностью.

Понятие недвижимости после недвижимое достаточно длительного воды формального отсутствия доме вернулось в гражданский и близкий хозяйственный оборот После нашей страны хозяйственный сравнительно недавно. договор Впервые этот дал термин был Впервые упомянут в п. 3 ст. 7 Даже Закона о собственности в Кроме РСФСР.

В период граждан господства командно-административной жилого системы недвижимость леса была в основном обусловлено объектом государственной свойств собственности. В редких движимое случаях допускалось дома право собственности не граждан на тормозилось отдельные виды были недвижимости (например, на господства жилые дома). участки Это было коллектива обусловлено тем, не что земля, Понятие недра, воды и длинной леса являлись течение исключительной собственностью что государства, а в собственности господства гражданина можно течение было иметь после только один купли дом. Соответственно, актом оборота недвижимости само не было и основу поэтому не допускалось было необходимости купли вводить само такого понятие.

Хотя или советское гражданское первая право не вводить давало легального участки понятия недвижимости, в словами ГК РСФСР 1964 г. виды содержались нормы, общую выделявшие право течение собственности на правовые такого рода Даже вещи и совершение оборота сделок с ними в имущества отдельные правовые земля институты (личная собственность близкий на жилой разграничения дом, договор исключительной купли-продажи жилого развитие дома или термина дачи).

Даже того при отсутствии дома права собственности оперировать на земельные легального участки для оперировать строений был режим создан особый природных правовой режим, РФ близкий к режиму связи недвижимости. Законодатель были был вынужден теми пользоваться длинной положен описательной формулой. вводить Слова «жилой дом (часть распада дома), квартира в само многоквартирном доме отсутствием жилищного строительного первая коллектива индивидуальных свойств застройщиков» были можно теми заменителями создан термина «недвижимость», которыми близкий приходилось оперировать.

ГК РСФСР 19864 г. внес изменения в право собственности:

a) запретил любые формы частнопредпринимательской деятельности (ст. 105 ГК РСФСР устанавливала, что имущество, находящееся в личной собственности граждан, не может использоваться для извлечения нетрудовых доходов);

б) закрепил собственность профсоюзных и иных общественных организаций в качестве самостоятельной формы собственности (согласно ст. 102, право распоряжения имуществом, составляющим собственность профсоюзных и иных общественных организаций, принадлежит исключительно самим собственникам);

в) ограничил право оперативного управления государственным имуществом от права собственности государства на это имущество:

- государство признается единственным собственником всего государственного имущества;

- государственная организация, которая имеет на правах оперативного управления то или иное государственное имущество, может владеть, 
пользоваться и распоряжаться этим имуществом в строго определенных законом пределах;

г) признал существование межколхозных организаций и объединений, а также государственно-колхозных и государственно-кооперативных организаций как юридических лиц.

такого После распада собственность СССР развитие жилые рынка недвижимости в командно РФ в течение жилые длительного времени положен тормозилось отсутствием обусловлено необходимой правовой собственность базы. Основополагающим гражданское правовым актом в пользоваться сфере недвижимости купли стала часть длинной первая Гражданского недвижимость кодекса РФ, на который дал недра общую характеристику которыми недвижимости. В основу был разграничения имущества был на движимое и тормозилось недвижимое был вынужден положен традиционный случаях для дореволюционного обусловлено российского права основном критерий физических, страны природных свойств создан вещи, или, системы другими словами, режиму критерий прочности договор связи с землей. Кроме того, ГК РФ указал на необходимость государственной регистрации прав на недвижимое имущество и сделок с ним.

Однако требовалась действующему более конкретная и возникающие подробная регламентация все такой регистрации, дела для чего важный надо было Например принять специальное электронной законодательство. После новый принятия Федерального актов закона «О государственной процедура регистрации прав основании на недвижимое шаг имущество и сделок с исключительно ним» и других заявления правовых актов, было ситуация начала дела меняться. С принятием форме указанного Закона учет был сделан системы важный шаг в исключениями формировании системы ведется государственного контроля нотариусов за сделками с за недвижимостью, а правила учет совершения сделок с органов недвижимостью сформулированы правообладателя достаточно четко и ситуация определенно.

Деление вещей водные на движимые и понятия недвижимые для как гражданского оборота понятия имеет фундаментальное обособленные значение. Такая РСФСР классификация существенным связи образом определяет было гражданско-правовой режим всеми вещи. Статья 130 недвижимостью ГК РФ понятия закрепляет понятие значение недвижимости. Недвижимое гражданско имущество (недвижимость) - это подлежат земельные участки, фундаментальное участки недр, подлежат обособленные водные обстоятельств объекты и все, не что прочно прежде связано с землей, обособленные то есть полной объекты, перемещение ряд которых без отказался несоразмерного ущерба вещей их назначению не невозможно, в том несоразмерного числе леса, движимых многолетние насаждения, вещи здания, сооружения, Вопрос объекты незавершенного обстоятельств строительства. К объектам недвижимости недвижимости кодекс назначению так же советского относит ряд имущества движимых вещей, заменил которые подлежат правовыми государственной регистрации.

В июле 2015 при года на наем смену действующему обременения Федеральному закону наем от 21 июля 1997 г. № 122-Ф3 «О государственной регистрации прав на недвижимое имущество и сделок с ним» Федеральному был принят более новый закон, основании который с 1 января 2017 при года (за некоторыми органом исключениями) будет все регулировать все регламентация процедуры регистрации приема недвижимости. В новом регистрировать законе предусмотрено, на что с отдельных актов случаях решено порядке регистрировать ограничения предусмотрено прав и обременения контроля недвижимого имущества, в т. ч. принятием сервитут, ипотека, информационного доверительное управление, все аренда, наем. января Предусмотрена единая системы учетно-регистрационная процедура. других Будет сформирован правила Единый государственный государственной реестр недвижимости (ЕГРН). января Последний ведется будет исключительно в электронной обременения форме. В него что войдут кадастр что недвижимости, реестр правовой прав на что нее, реестр возникающие границ, реестровые или дела, кадастровые органов карты, книги границ учета документов. 
конкретная Будут регистрировать недвижимости права, возникающие в был силу закона, Уточнены без заявления кадастрового правообладателя или государственной правоприобретателя. Процедура системы совершается на реестр основании сведений, конкретная поступающих в порядке правообладателя информационного взаимодействия недвижимостью от органов и новом нотариусов.

Уточнены подробная пределы правовой поступающих экспертизы при карты государственной регистрации исключительно прав.

Сокращены органом сроки кадастрового без учета и регистрации что прав. Им сформулированы посвящена отдельная смену статья. Например, 5 контроля рабочих дней - с важный даты приема Последний органом регистрации июля заявления на от кадастровый учет и случаях прилагаемых к нему учет документов. 7 рабочих ситуация дней - с даты что приема заявления заявления на регистрацию от прав.

Распределена ответственность за действия (бездействие) органов и лиц, участвующих в правоотношениях.

Таким образом, действующее гражданское законодательство не только производит разделение вещей на движимые и недвижимые, но также дает легальное определение недвижимого имущества и детально регулирует его оборот. В целом, нормативные акты, принятые в период с 1990 г. по настоящее время, обеспечили включение рыночных отношений в сферу недвижимости, и сейчас абсолютно уверенно можно говорить о недвижимости как о товаре, который повсеместно продается и покупается.

$$
* * *
$$

1. Конституция Российской Федерации (принята всенародным голосованием 12.12.1993) (с учетом поправок, внесенных Законами РФ о поправках к Конституции РФ от 30.12.2008 № 6-ФКЗ, от 30.12.2008 № 7-ФКЗ, от 05.02.2014 № 2-ФКЗ, от 21.07.2014 № 11-ФКЗ) // Российская газета. 1993. № 237.

2. Гражданский кодекс Российской Федерации (часть первая) от 30.11.1994 № 51-Ф3 (ред. от 29 июля 2017 г. N 259-Ф3) // Собрание законодательства РФ, 05.12.1994, № 32, ст. 3301.

3. Гражданский кодекс Российской Федерации (часть вторая) от 26.01.1996 № 14-Ф3 (ред. от 29 июля 2017 г. N 259-Ф3) // Собрание законодательства РФ,29.01.1996, № 5, ст. 410.

4. Земельный кодекс Российской Федерации от 25.10.2001 № 136-Ф3 (ред. от 29 июля 2017 г. N 280-Ф3) // Собрание законодательства РФ, 29.10.2001, № 44, ст. 4147..

5. Федеральный закон от 13 июля 2015 г. N 218-Ф3 «О государственной регистрации недвижимости» (в ред. от 29 июля 2017 г. N 280-Ф3) // Собрание законодательства Российской Федерации от 20 июля 2015 г. N 29 (часть I) ст. 4344.

6. Гражданский кодекс РСФСР от 11 июня 1964 г. // Ведомости Верховного Совета РСФСР от 18июня 1964 г. №24. Ст. 406. (утратил силу).

7. Постановление ВЦИК от 11.11.1922 «О введении в действие Гражданского кодекса Р.С.Ф.С.Р.» (вместе с «Гражданским кодексом Р.С.Ф.С.Р.») // «СУ РСФСР», 1922, N 71, ст. 904 (Утратил силу).

8. Закон РСФСР от 24 декабря 1990 г. «О собственности в РСФСР» // Ведомости Съезда народных депутатов РСФСР от 27 декабря 1990 г. №30. Ст. 416. (утратил силу)

9. Виноградов П. Недвижимое имущество: историческое и современное понимание // Бюллетень нотариальной практики. 2014. № 2.

10. Гражданское право: учебник для вузов. Ч. 1 / Моск. гос. юрид. акад.; отв. ред.: В. П. Мозолин, А. И. Масляев. - М.: Юристъ, 2015.

11. Егоров Н. Д. Проблемы разграничения движимых и недвижимых вещей в гражданском праве // Вестник ВАС РФ. 2017. № 7. С. 4 - 29.

12. Киндеева Е. А., Пискунова М. Г. Недвижимость: права и сделки (новые правила оформления, государственная регистрация, образцы документов) / Киндеева Е. А. - М.: Юрайт-Издат, 2015.

13. Кущенко В. В. Правовой режим недвижимости: проблемы и пути их решения // Законодательство и экономика. 2016, № 10. С. 31 - 34.

14. Лунева Е. В. Юридическая конструкция гражданско-правового режима вещей // Юрист. 2014, № 13. С. $41-46$.

15. Недвижимое имущество и сделки с ним: правовые проблемы регулирования, долевой собственности, многообразия объектов, правил регистрации / разраб. темы, советы и рекоменд. С. П. Гришаева. - М.: Рос. газ., 2016.

16. Степанов С. А. Недвижимое имущество в гражданском праве / С. А. Степанов. - М.: Статут, 2014.

17. Чубаров В. В. Проблемы правового регулирования недвижимости / В. В. Чубаров. - М.: Статут, 2016. 